\title{
CLONE PRODUCTION FROM PELARGONIUM GRAVEOLENS L'HERIT. TOLERANT TO WILT THROUGH TISSUE CULTURE
}

\author{
A. M. A. Hamouda*, A. B. Abd-Elrazek** and M. A. Baiuomy*** \\ * MAPS Department, Horticulture Research Institute, Agriculture Research \\ Center, Giza, Egypt. \\ ** Genetic Department, Faculty of Agriculture, Ein-Shams University, \\ Egypt. \\ ***Plant Pathology Research Institute, Agric. Res. Center, Giza, Egypt.
}

\section{ABSTRACT}

This work was carried out in the plant tissue culture laboratory of the Vegetable and Medicinal Plant Research Department, Horticulture Research Institute, Ministry of Agriculture, during the period of 2004 to 2008 to produce geranium (Pelargonium graveolens L, Herit.) clones that tolerate to fusarium wilt through tissue culture. The study included three items:

1- Callus induction, callus differentiation and acclimatization.

2- Fungal infection of fusarium in the pots of the tested clones.

3- Evaluation of clones compared with mother plants.

- Wilt percentage after the plants were infected with fusarium fungal

- Morphological characteristics for clones and mother plants and essential oil percentage \& constituents.

- DNA and protein isolation for clones and mother plants

The obtained results were as follow:-

- Obtaining of two clones from Pelargonium graveolens L, Herit., tolerate to fusarium wilt

- There were true significant different between two clones and mother plant in leaves area characteristics and oil percentage

- There were variation in DNA isolation between two clones and mother plant

As such we recommended propagating this clones and increasing its cultivated area to come over geranium wilt disease.

Key words: DNA, Callus induction, Pelargonium graveolens, evaluation, mother plants. 


\section{INTRODUCTION}

Pelargonium graveolens L, Herit. has a major part in the production of medicinal and aromatic plants in Egypt and cultivated in many Governorates such as Beni Seuf, El Gharbia, El Kalubeya and El Fayoum.

The genus Pelargonium is a member of the family Geraniaceae in which also includes the genera Geranium, Erodium, Monsonia, and Sarcocaulon. The vast majority of the 250 or so natural species of Pelargonium derive from South Africa, although a few species are native to Australia, East Africa and Syria. The genus is subject to large morphological diversity and for descriptive purposes, has been subdivided into 15 , or sometimes 16 sections (or subgenera) based on leaf and flower characteristics and on habitat. The leaves of many species and numerous artificial hybrids are scented, and members of the subgenera Pelargonium, Cortusina and Polyactium appear to be especially rich in essential oil (Webb, 1984).

The essential oil is obtained by steam distillation of the green herb either directly after harvesting, or after $24 \mathrm{~h}$ in order to reduce the volume and to release the oil from the glycosidal form. Yields of oil vary according to the time of harvesting and, of course, environmental factors. Maximal oil content of up to $0.4 \%$ may be obtained from herbage harvested just before and during flowering (Fleisher and Fleisher, 1985).

Commercial geranium oil is a complex mixture of over 120 mono-and sesquiterpenes and low molecular weight aroma compounds, the main components are geraniol, citronellol, linalool, menthol, eugenol and other esters, and together these components constitute $60-70 \%$ of the total oil (Vernin et al., 1983).

Geranium plant has been observed to be generally affected by four fungal pathogens. Rhizoctonia solani and Fusarium oxysporum var. redolens are highly prevalent in the southern hilly tracts, while Alternaria alternata, Colletotrichum gloeosporioides and Colletotrichum acutatum cause severe leaf blight in the northern Indian plains (Alam et al., 2007). Disease losses (54.9 \& $58.4 \%$ ) and $(63.5 \& 75.0 \%)$ in geranium herb and oil yield for plants grown in rows and plots, respectively (Arafa et al. 1998).

Because the crop is polyploid and highly sterile, traditional breeding cannot be carried out. Somatic mutation and genetic engineering techniques appear to be most suitable for incorporating disease resistance in such vegetatively propagated plants (Bi et al., 1999).

Skirvin and Janick (1976) mentioned that, the calliclones of scented Pelargonium spp showed high variability comparing to mother plant and calliclone variation was dependent upon clone and age of callus. Also Gauri et al. (2000) obtained calliclones from Pelargonium graveolens Indian cultivar 
Hemanti which some of them was resemble to mother plant and the other differed in several herb related agronomic characteristics.

Somaclonal breeding programmers have proved extremely successful in developing disease-resistant cultivars in a number of crop species Thakur et al., (2002). It has either been attempted at the plant level where a large population of plants, raised through in vitro callus cultures, have been screened for resistance in the field directly or via a more targeted approach of regeneration of diseaseresistant plants through resistant callus cultures selected against fungal toxin Hammerschlag, (1992).

Matsumoto (1995) investigated an increased tolerance of the selected Maca banana plants to the race 1 fungus in greenhouse tests. It is concluded that in vitro selection by fusaric acid is a useful method for obtaining fusarium disease tolerance, although the tolerance mechanism of the selected plants may be different from that of the existing tolerant cultivars .

Saxena (2008) demonstrated that, the induction of disease resistance in rose-scented geranium plants was found at the cellular level. This approach could be successfully exploited in raising new disease-resistant cultivars in geranium against various fungal pathogens.

These reviewed results confirm the need to produce the wilt tolerant clones. So this work aimed to produce and evaluate of some clones from callus formation through tissue culture technique which promising as fusarum wilt tolerant of high productivity of herb and oil as well as oil of good quality.

\section{MATERIALS AND METHODS}

This work was carried out on Pelargonium graveolens L, Herit. plant to produce clones tolerant to fusarium wilt through tissue culture, during the period from 2004 to 2008, in the plant tissue culture Laboratory of the Vegetable and Medicinal Plant Research Department, Horticulture Research Institute, Ministry of Agriculture.

\section{In vitro and acclimatization stage:}

\section{1- Callus induction:}

The explants (internodes segments of $1 \mathrm{~cm}$ length and $0.5 \mathrm{~cm}$ thickness) were taken from terminal cuttings and washed under running tap water for one hour, then surface sterilized by immersing in sodium hypochlorite $0.8 \%$ and 2 drops of tween 20 emulsifier for 20 minutes, then rinsed three times in sterile distilled water containing $0.5 \mathrm{~g} / \mathrm{L}$ PVP for 5 minutes to prevent browning. After surface sterilization, the external parts of explants were removed and the explants of $3 \mathrm{~mm}$ length placed onto the nutrient medium. After preparation the medium 
and prior to agar addition, the $\mathrm{pH}$ was adjusted to 5.8. According to the stages of this work, the medium was poured into either culture tubes of size $2.5 \mathrm{x} 15 \mathrm{~cm}$ or jars $(175 \mathrm{ml})$ where each tube contained $10 \mathrm{ml}$ and each jar contained $15 \mathrm{ml}$ of the medium. The tubes were covered with aluminum foil while the jars were capped with polypropylene closures. The culture vessels were autoclaved at $121^{\mathrm{O}} \mathrm{C}$ and $1.2 \mathrm{Kg} / \mathrm{cm}^{2}$ air pressure for 20 minutes.

Murashige and Skoog (MS, 1962) basal medium was used in this experiment of this study. The medium contained $30 \mathrm{~g} / \mathrm{L}$ sucrose and $6 \mathrm{~g} / \mathrm{L}$ agar. The used growth regulators for this purpose was $2.5 \mathrm{mg} / \mathrm{L}$. BA $+0.5 \mathrm{mg} / \mathrm{L}$ NAA, Hamouda, (2003).

The experiment are divided into five treatments from fusaric acid 0.0, $0.1,0.5,1.0$ and $1.5 \mathrm{mg} / \mathrm{L}$.

The explants were cultured on the medium at November 2005 aiming to callus induction.. Each treatment was represented by 12 tubes, each tube contained one explant, then the cultured tubes were kept at $25 \pm 2{ }^{\circ} \mathrm{C}$ with light intensity 1500 lux for $16 \mathrm{hr}$. photoperiod provided by cool white fluorescent lamps. Data were recorded after six weeks including percentage of callus induction and callus weight.

\section{2- Callus differentiation (organogenesis):}

Fifty tubes were cultured on the best concentration callus differentiation (MS basal medium supplemented with $10 \mathrm{mg} / \mathrm{L}$ Kin), Hamouda (2003) this concentration divided into five treatment from fusaric acid 0.0, 0.1, 0.5, 1.0 and $1.5 \mathrm{mg} / \mathrm{L}$. for obtaining callus differentiation Then, data were recorded as, differentiation percentage (cultures showed shoots only, roots only or both), plant length, leaf number and root length.

\section{3-Acclimatization:}

The acclimatization of the produced plantlets (four plantlets from $0.1 \mathrm{mg} / \mathrm{L}$ fusaric acid and four plantlets from $0.5 \mathrm{mg} / \mathrm{L}$ fusaric acid) planted in plastic pots $(7.5 \times 10.5 \mathrm{~cm})$ containing peatmoss: vermiculite $(1: 1 \mathrm{v} / \mathrm{v})$, every pot contained one plantlet covered with plastic bag to maintain high relative humidity in the greenhouse. The plastic bags were bored by needle twice every day in order to get rid of excess humidity. The bags were removed after one month. The obtained seedlings were transferred into sand: clay mixture $(1: 1 \mathrm{v} / \mathrm{v})$ in $30 \mathrm{~cm}$ pots and kept to grow for six months, then they were cut and the obtained cuttings were cultured in pots to make tow groups (clone 1 and clone 2) and kept to grow for six months to infect with fusarium fungal.

\section{Source of $F$. oxysporum isolate:}

The virulent isolate of $F$. oxysporum of Pelargonium graveolens L'Herit. used in this study was gently obtained from the stock of the isolated fungi of 
Ornamental, Medicinal and Aromatic Plant Diseases Department, Plant Pathology Research Institute, Agric. Res. Center, Giza, Egypt. The fungus was grown on potato dextrose liquid media (200 g. potatoes and $20 \mathrm{~g}$. dextrose per liter of medium) in $500 \mathrm{ml}$ glass bottles. The inoculated bottles were incubated at $25^{\circ} \mathrm{C} \pm 1$ for 15 days Hasan, Wafaa (2006).

\section{Greenhouse experiment:}

Soil infestation was carried out by mixing the pathogen inoculums thoroughly with formalin sterilized soil at the rate $(3 \%)$ of soil weight. The infested soil was then placed in formalin sterilized pots $(25 \mathrm{~cm}$ in diam.). Five pots were used for each treatment, and each pot was considered as one replicate .Commercial variety of pelargonium cuttings were obtained from The Horticulture Research Institute, MAPs Department and surface sterilized using sodium hypochlorite (1\%) solution for $3 \mathrm{~min}$. and planted at the rate 3 cuttings/pot. Percentage of wilt infection were recorded 90 days after the planting date Dhingra and Sinclair (1995).

\section{Evaluation of clones compared with mother plants;}

\section{1- Vegetative growth:}

These clones were compared with mother plant seedlings propagated by cuttings after infection in the pots at the same time. The evaluation of two cuts/ year included wilt percentage after fusarium infection, plant height, branch number, stem fresh weight, leaves number, leaves fresh weight, leaf area $\mathrm{cm}^{2}$ and plant fresh weight.

\section{2- Oil percentage and constituents:}

Oil percentage of the fresh herb was determined according to the method described in the British Pharmacopoeia (1963). Gas liquid chromatography (GLC) method was used to analyze the essential oil for the main components.

\section{3- DNA isolation:}

\section{Polyacrylamide gel electrophoresis:}

Fresh leaf samples from Pelargonium graveolens L'Herit. were homogenized in $200 \mathrm{ul}$ buffer containing $1 \mathrm{M}$ Tris-Hcl pH 8.8 and $0.25 \mathrm{M}$ EDTA. After centrifugation at $10,000 \mathrm{rpm}$ for $10 \mathrm{~min}$., 100ul supernatant containing water soluble proteins were transferred to a new eppendorf tube and mixed with 800 ul acetone and then kept in freezer for 15 mion., after centrifugation at $10000 \mathrm{rpm}$ for $10 \mathrm{~min}$., the pellets were suspended in $80 \mathrm{ul}$ buffer containing $1 \mathrm{M}$ Tris $-\mathrm{Hcl} \mathrm{pH}$ 8.8, 0.25 M EDTA, 10\% SDS and 10\% glycerol. Mercaptoethanol was added to each tube and boiled in water bath for 10 min. Polyacrylamide gel electrophoresis (PAGE) in sodium dodecyl sulfate was performed on $12.5 \%(\mathrm{w} / \mathrm{v})$ polyacrylamide gels according to Sambrook et al., 
(1989). After electrophoresis, gels were stained with $0.02 \%$ (w/v) Coomassie Brilliant Blue R-250 (Sigma). A value of the relative molecular mass (Mr) of the protein band was estimated by comparison with the molecular weight marker (Bio Rad).

\section{Protein measurement}

The protein content of the samples was measured according to Lowry et al., (1951) with bovine serum albumin as standard protein. Measurements were carried out at $595 \mathrm{~nm}$.

\section{Plant DNA extraction}

Leaves of Pelargonium graveolens L'Herit. were collected, quickly frozen in liquid nitrogen, and ground to a fine powder. Total genomic DNA was extracted and purified from $1 \mathrm{~g}$ of freeze-dried powder as described by Dellaporta et al., (1983). DNA present in the supernatant was precipitated according to the described protocol, re-dissolved in sterile, distilled water and quantified by spectrophotometer.

\section{Amplification of genomic DNA using polymerase chain reaction (PCR)}

PCR was performed with final volume of $25-\mu 1$ according to Williams et al., (1990). Four random DNA oligonucleotide primers were independently used in the PCR reactions (UBC University of British Colombia, Canada) the primers with the following sequence UBC21 5'ACCGGGTTTA3' UBC30 5' CCGGCCTTAG3', UBC75 5'GAGGTCCAGA3' and UBC82 5'GGGCCCGAGG3'

The amplification was carried out as follows, one cycle $94^{\circ} \mathrm{C}$ for $4 \mathrm{~min}$, 37 cycles $94^{\circ} \mathrm{C}$ for $45 \mathrm{sec}$., $36^{\circ} \mathrm{C}$ for $1 \mathrm{~min} ., 72^{\circ} \mathrm{C}$ for $2 \mathrm{~min}$., and one cycle at 72 ${ }^{\circ} \mathrm{C}$ for 12 min., then $4{ }^{\circ} \mathrm{C}$ infinitive. To check the PCR products, agarose gel electrophoresis was employed a DNA marker (100 ladder (Roche)) Electrophoresis took place in $1 \mathrm{X}$ TBE buffer for $30 \mathrm{~min}$., at 100 volts. After staining with ethidium bromide, the gel was photographed.

\section{Gels analysis:}

All gels resulted from the two genetic criteria, protein and DNA Fingerprints, were scanned and analyzed with Bio-Rad video densitometer model 620.

The following data were recorded on geranium clones and mother plants:

Data in tissue culture laboratory:

1- Percentage of callus formation.

2- Callus weight (g.).

3- Callus differentiation percentage.

4- Shoot and root lengths (cm).. 
5- Leaves number.

\section{Data in open field plants:}

1- Wilt percentage after fungal infection.

2- Plant height $(\mathrm{cm})$.

3- Number of branch and leaves.

4- Leaves, stems and plant fresh weight (g.).

5- Leaf area $\left(\mathrm{cm}^{2}\right)$.

6- Oil percentage, yield $\mathrm{ml} /$ plant and constituents.

7- DNA isolation.

8- Protein isolation.

Data were subjected to analysis of variance and least significant different Test was used to compare the obtained means at $1 \%$ and 5\% levels ( Snedecor and Cochran, 1980).

\section{RESULTS AND DISCUSSION}

\section{1- Callus formation:}

Data in Figure 1 and Table 1 indicated that, control and control +0.1 $\mathrm{mg} / \mathrm{L}$ fusaric acid showed successful effect on callus formation of the cultured internodes.

The higher percentage of callus formation $(80 \%)$ and callus weight (0.425 g.) were obtained when MS medium was free from fusaric acid, while the other treatments which contain different concentrations from fusaric acid $(0.5,1.0$ and $1.5 \mathrm{mg} / \mathrm{L})$ had no effect on callus formation of the cultured internodes. The exception was found in one concentration $0.1 \mathrm{mg} /$ L fusaric acid which gave $40 \%$ callus formation and callus weight $(0.371$ g.).These data were in accordance with Matsumoto et al (1995).

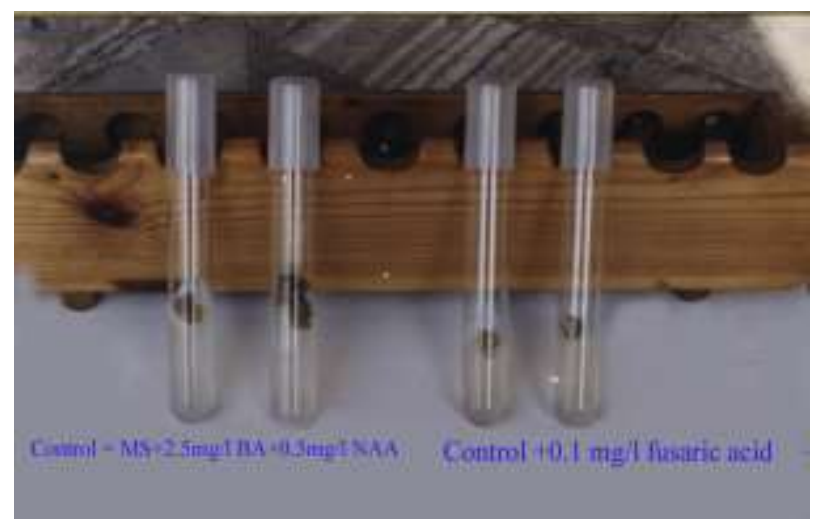

Figure 1. Callus formation 
Table 1. Effect of different concentrations of fusaric acid on the percentage of callus induction and weight of formed callus/ explant (g.) from internodal explants of Pelargonium graveolens L'Herit.

\begin{tabular}{lcccc}
\hline \multicolumn{2}{c}{ Treatments } & & \multicolumn{2}{c}{ Callus } \\
\cline { 3 - 5 } Control+ & & & Formation \% & Weight (g.) \\
\cline { 2 - 5 } & F. acid mg/ L. & $\mathbf{0 . 1}$ & $\mathbf{8 0 . 0}$ & $\mathbf{4 0 . 0}$ \\
& & $\mathbf{0 . 5}$ & $\mathbf{0 0 . 0}$ & $\mathbf{0 . 3 7 1}$ \\
& & $\mathbf{1 . 0}$ & $\mathbf{0 . 0}$ & $\mathbf{0 . 0}$ \\
& & $\mathbf{1 . 5}$ & $\mathbf{0 . 0}$ & $\mathbf{0 . 0}$ \\
& &
\end{tabular}

Control $=\mathrm{MS}+2.5 \mathrm{mg} / \mathrm{L} . \mathrm{BA}+0.5 \mathrm{mg} / \mathrm{L} . \mathrm{NAA}$.

\section{2- Callus differentiation (Organogenesis):}

Data in Table 2 and Figure 2 showed that, differentiation percentage reached the highest value (90\%) when callus was cultured on MS medium containing $10.0 \mathrm{mg} / \mathrm{l} \mathrm{Kin}$ without supplemented fusaric acid (control), while differentiation percentage achieved $40 \%$ at the low concentration from fusaric acid (control+ 0.1 and $0.5 \mathrm{mg} / \mathrm{L}$ fusaric acid).

Date clearly indicated that, fusaric acid affected negatively in callus differentiation i.e. the lower concentration (control+ 0.1 and $0.5 \mathrm{mg} / \mathrm{L}$ ) exerted an inhibiting effect on shoot length $(6.17$ and $5.33 \mathrm{~cm})$ in comparison with control $(9.34 \mathrm{~cm})$.

It was also showed that, fusaric acid at the highest concentration (1.0 and $1.5 \mathrm{mg} / \mathrm{L}$ ) showed the greatest inhibiting effect in callus differentiation.

Moreover, the root length and leaves number showed an inhibiting effect due to fusaric acid supplement. In this concern, the inhibiting effect of fusaric acid was found to be parallel with its concentration, i.e. increasing the concentration of fusaric acid showed an increase of its inhibiting effect as illustrated in Table 2.

This detected inhibiting effect of fusaric acid on callus differentiation, shoot length, root length and leaves number may be due to that fusaric acid exert an harmful effect on the hormonal balance as well as the favorable balanced conditions of the callus differentiation and organs growth

\section{Evaluation of the resultant plants under field conditions:}

Two clones were obtained from culturing of cuttings taken from the acclimatized plants which were previously regenerated from callus grown in MS media supplemented with fusaric acid. These clones were compared with mother plant seedlings cultured by cuttings at the same time in the same pots. 
Table 2. Effect of different concentrations of fusaric acid on the percentage of callus differentiation (organogenesis), shoot and root length, and leaves number of Pelargonium graveolens L'Herit.

\begin{tabular}{|c|c|c|c|c|c|c|}
\hline \multirow{2}{*}{\multicolumn{3}{|c|}{ Treatments }} & \multirow{2}{*}{$\begin{array}{c}\text { Callus } \\
\text { differentiation }(\%)\end{array}$} & \multicolumn{2}{|c|}{ Length (cm) } & \multirow{2}{*}{$\begin{array}{l}\text { Leaves } \\
\text { number }\end{array}$} \\
\hline & & & & Shoot & Root & \\
\hline \multirow{5}{*}{ Control+ } & \multicolumn{2}{|c|}{------- } & 90.0 & 9.34 & 4.89 & 8.45 \\
\hline & F. acid & 0.1 & 40.0 & 6.17 & 4.0 & 7.17 \\
\hline & $\mathrm{ml} / \mathrm{L}$ & 0.5 & 40.0 & 5.33 & 3.67 & 5.67 \\
\hline & & 1.0 & 0.0 & 0.0 & 0.0 & 0.0 \\
\hline & & 1.5 & 0.0 & 0.0 & 0.0 & 0.0 \\
\hline L.S.D. at 5 & & & & 1.73 & N.S & N.S \\
\hline L.S.D. at 1 & & & & 2.62 & N.S & N.S \\
\hline
\end{tabular}

Control $=$ MS+10.0 mg/ L. Kin
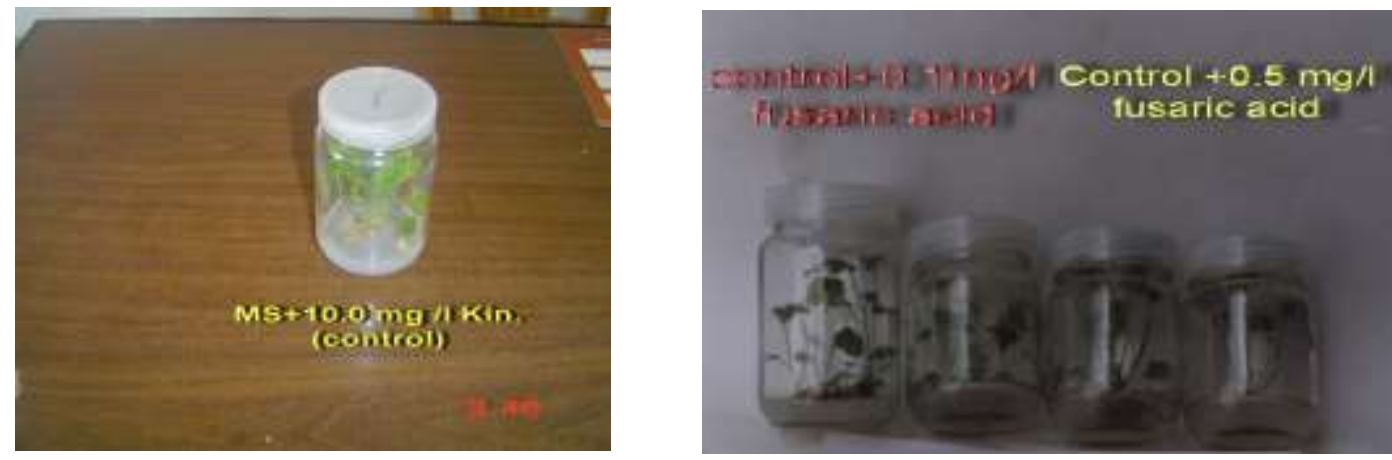

Figure 2. Callus differentiation
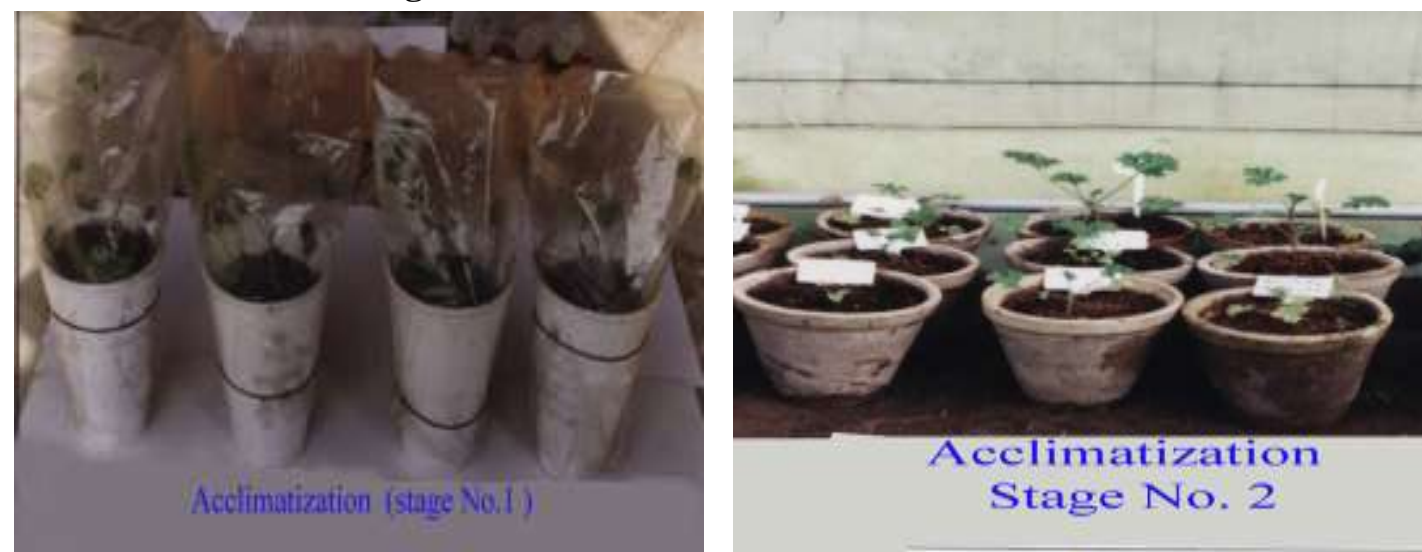

Figure 3. Acclimatization 


\section{1 - Survival percentage after artificial fungal infected:}

Data in Table (3) emphasized that, the survival percentage (100\%) of the two clones and $(60 \%)$ of mother plants after artificial fungal infection.

It is clear that, two clones were tolerant to Fusarium oxysporum infection more than mother plants.

Table 3. Survival percentage after fungal infection

\begin{tabular}{lc}
\hline \multicolumn{1}{c}{ Clones } & $\begin{array}{c}\text { Survival percentage after fungal } \\
\text { infection }\end{array}$ \\
\hline Mother plants & 60 \\
Clone (1) & 100 \\
Clone (2) & 100 \\
\hline
\end{tabular}

\section{2- The vegetative growth, oil percentage and constituents:}

Data in Table (4) showed the vegetative characteristics of the resultant clones, in the first cut, significant increase was found in plant height while, high significant decrease in leaves fresh weight was obtained in comparison with mother plants.

On the other hand the rest of vegetative characters (number of branch, number of leaves, stem fresh weight and leave area) showed no significant differences between two clones and mother plant.

In the second cut data in Table (4) clear that, leaves area $\left(\mathrm{cm}^{2}\right)$ of the two clones showed insignificant difference than mother plant. On the same way, plant height, number of branch, number of leaves, leaves fresh weight (g.), stem fresh weight (g.) and plant fresh weight (g.) recorded insignificant differences between the two clones and the mother plant.

\section{Essential oil yield:}

\section{1 - Oil percentage and oil yield ( $\mathrm{ml} /$ plant):}

Essential oil percentage of the two cuts is shown in Table 5. In the first cut, the highest oil percentage $(0.133 \& 0.13 \%)$ was obtained from the clone $(2 \& 1)$ respectively, these values were significantly higher than mother plant $(0.09 \%)$.

In the second cut, similar trend were recorded, the highest percentage $(0.290 \%)$ was recorded in case of clone (2) followed by clone (1) $(0.287 \%)$ compared with mother plants $(0.113 \%)$.

However, the oil yield (ml)/ plant of the two cuts for the two clones were insignificantly higher than the mother plants. 
Table 4. Vegetative characteristics of some clones which obtained from different tissue culture conditions compared with the mother plant of Pelargonium graveolens L'Herit.

\begin{tabular}{|c|c|c|c|c|c|c|c|}
\hline \multirow{2}{*}{ Clones } & \multirow{2}{*}{$\begin{array}{l}\text { Plant } \\
\text { height } \\
\text { (cm) }\end{array}$} & \multicolumn{2}{|c|}{ Number of } & \multicolumn{3}{|c|}{ Fresh weight (g.) } & \multirow{2}{*}{$\begin{array}{l}\text { Leaf area } \\
-\quad\left(\mathrm{cm}^{2}\right)\end{array}$} \\
\hline & & Branch & Leaves & Leaves & Stem & Plant & \\
\hline \multicolumn{8}{|c|}{ First cut } \\
\hline Motherplant & 59.03 & 13.33 & 221.67 & 245.0 & 116.67 & 362.67 & 16.00 \\
\hline Clone (1) & 67.33 & 14.83 & 223.67 & 220.67 & 106.33 & 327.00 & 18.79 \\
\hline Clone (2) & 68.5 & 9.67 & 228.0 & 183.33 & 91.67 & 248.00 & 21.34 \\
\hline L.S.D. $5 \%$ & 4.83 & N.S & N.S & 27.4 & N.S & N.S & N.S \\
\hline \multicolumn{8}{|c|}{ d cut } \\
\hline Mother plant & 72.33 & 18.00 & 216.67 & 511.00 & 179.20 & 690.20 & 21.83 \\
\hline Clone (1) & 71.00 & 14.67 & 220.00 & 327.00 & 148.97 & 475.97 & 29.73 \\
\hline Clone (2) & 76.67 & 15.33 & 300.67 & 257.83 & 123.70 & 381.53 & 32.53 \\
\hline L.S.D. 5\% & N.S & N.S & N.S & N.S & N.S & N.S & 3.60 \\
\hline
\end{tabular}

\section{2 - Oil constituents of geranium clones:}

Data in Table 5 showed the percentages of the main oil constituents of the obtained calliclones.

Concerning geraniol percentage, the clone (2) showed an increase in geraniol content $(22.57 \%)$ when compared with mother plant $(20.95 \%)$. However, the lowest geraniol percentage $(17.52 \%)$ was produced from the clone (1).

As for citronellol content similar trend was showed, the highest percentage was recorded in case of clone (2) (31.45\%)followed by mother plant $(29.09 \%)$ and clone $(1)(26.85 \%)$ respectively.

However, the least linalool percentage $(5.00 \%)$ was obtained from the oil of clone (1) and the highest percentage was recorded in case of mother plant $(6.81 \%)$.

As for eugenol percentage, the highest percentage was recorded at clone (1) $(11.55 \%)$, followed by clone (2) $(8.15 \%)$ and mother plant $(8.11 \%)$ respectively.

These results indicated some differences in phenotype especially in leaf area in the two clones as well as their superiority in essential oil content in comparison with the mother plant. In this regard, Gauri et al (2000) obtained calliclones of Pelargonium graveolens LHerit. differed in several herb related agronomic characteristics such as plant height, herb yield, canopy size and number of branches per plant from the parental type as well as from the parent, which seems advantageous for commercial exploitation of such clones. 
Table 5. Oil percentage, oil yield ( $\mathrm{ml} /$ plant) and main constituents on geranium plants.

\begin{tabular}{|c|c|c|c|c|c|c|c|c|}
\hline \multirow{3}{*}{ Clones } & \multicolumn{8}{|c|}{ Geranium oil } \\
\hline & \multicolumn{2}{|c|}{ Percentage } & \multicolumn{2}{|c|}{$\begin{array}{l}\text { yield/ } \\
\text { plant (ml) }\end{array}$} & \multicolumn{4}{|c|}{ Main constituents \% } \\
\hline & $\begin{array}{l}1^{\text {st }} \\
\text { Cut }\end{array}$ & $\begin{array}{l}2^{\text {nd }} \\
\text { Cut }\end{array}$ & $\begin{array}{c}1^{\text {st }} \\
\text { Cut }\end{array}$ & $\begin{array}{l}2^{\text {nd }} \\
\text { Cut }\end{array}$ & Geraniol & Citronellol & Linalool & Eugenol \\
\hline Mother plant & 0.090 & 0.113 & 0.34 & 0.80 & 20.95 & 29.09 & 6.81 & 8.11 \\
\hline Clone (1) & 0.130 & 0.287 & 0.42 & 1.38 & 17.52 & 26.85 & 5.00 & 11.55 \\
\hline Clone (2) & 0.133 & 0.290 & 0.31 & 1.07 & 22.57 & 31.45 & 5.68 & 8.15 \\
\hline L.S.D. 5\% & 0.013 & 0.036 & NS & NS & -- & -- & -- & -- \\
\hline
\end{tabular}

Thus good agricultural practices may be needed to enhance herb yield of the wilt tolerant clone if chosen according to its high content of oil percentage. This may be of a great importance since some derived clones showed an increase in geraniol and linalool contents and all of the derived clones showed an increase in citronellol content compared to the mother plant.

\section{3 - Biochemical and molecular identification:}

The present investigation has been carried out to study the differences between mother plant and two clones and the similarities and genetic distance between the clones (1 and 2), which were collected from Pelargonium graveolens L' Herit. (mother plant) the goal of the present study has been achieved by employing to different criteria, i.e. protein banding patterns, and RAPD-PCR analysis.

\section{a- Bio-chemical genetic marker:}

Polyacrylamid gel electrophoresis (PAGE) technique was used to identify the three different breeds under investigation. Figure 4 shows the electrophoretic patterns of soluble protein of the plant samples.

The most important variation to be studied in plant breeds as detected by anodic polyacrylamide gel electrophoresis for acidic proteins the result agreement with Recorbet et al., (1998) who detect acidic protein in tomato plant after inoculation with the strains of $F$. oxysporum f. sp. lycopersici.

Electrophoretic SDS-protein patterns of fresh leaf samples for the three Pelargonium graveolens L, Her. (clone $1 \& 2$ and mother plant) are shown in Fig. 4 considering band's number, the three line showed high similarity, which suggesteds high genetic background similarity within these genotypes. However, interspecific differences in band's number between the treated and original were identified. No variations were detected with regard 
to band's number, and no differences in band's intensity. According to the presence of band at arrows (at approximately molecular weight 27.5, 26, 21.5 and $14.5 \mathrm{KD}$ ) were detect in selected plant. These bands are low molecular weight and acidic proteins. These results are in agreement with Recorbet et al., (1998) who detected by polyacrylamide gel electrophoresis for acidic proteins after inoculation, the strains of $F$. oxysporum f.sp. lycopersici .

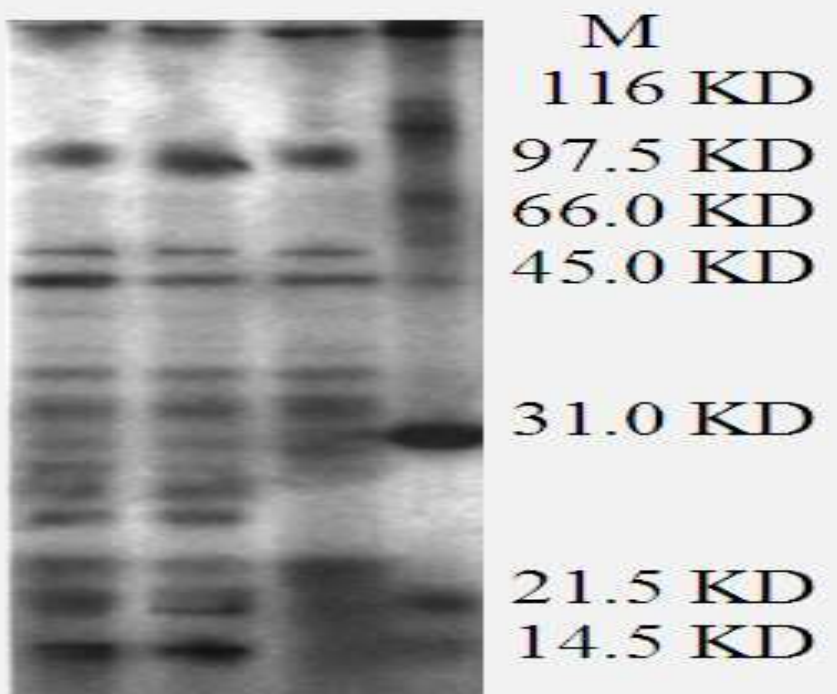

Figure 4: SDS- Protein banding pattern of three Pelargonium graveolens $\mathbf{L}$ Herit. lane $M$ referees to the standard protein marker.

\section{b - DNA isolation:}

The isolated DNA from three line of Pelargonium graveolens $L$ were tested against four 10-mer random primers. The results of RAPD analysis using four primers UBC 21, UBC30, UBC75 and UBC 82 fore three lines of are illustrated in Fig. (5). The molecular size of the PCR products generated by these primers are ranged from approximately 2500 to $250 \mathrm{bp}$. The primers UBC 21, $\mathrm{UBC} 30, \mathrm{UBC} 75$ and UBC82 generate unique bands at $\simeq 1580, \simeq 506, \simeq 470$ and $\simeq$ 517 respectively in selected line and absent in original. According to these observations, RAPD analysis was completely discriminates among the three lines. The obtained data across SDS and RAPD, which indicates a high level of genetic background similarity studied lines. 


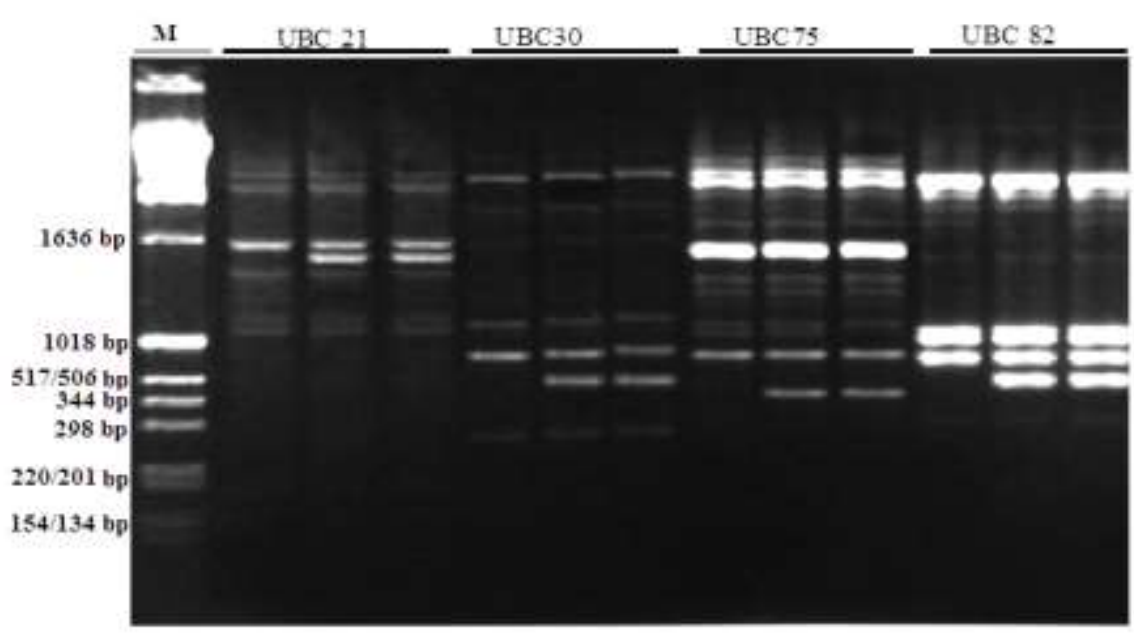

Figure 5: DNA polymorphism based on RAPD analysis for three Pelargonium graveolens L'Herit. line.

Plants possess a broad spectrum of basic defense mechanisms, preestablished or induced, which render them resistant to most potential colonizers. The ability of $F$. oxysporum strains to tolerate or delay host defenses has been proposed as a trait that may reflect pathogenicity on a specific host. Olivain and Alabouvette $(1997,1999)$ demonstrated, on the basis of cytological observations, that whereas the colonization of the nonpathogenic GUS-marked strain was restricted to the superficial layers of cells by the defense reactions of the plant. Apart from cytological observations, few studies have adressed the expression of plant defenses in response to both pathogenic and nonpathogenic $F$. oxysporum. Among them, special attention has been paid to the secondary metabolites produced by plants, many of which have antifungal activity. Saponins, which are plant glycosides, have been implicated as preformed chemical barriers against pathogen attacks (Osbourn, 1996). $\alpha$-tomatine, a phytoanticipin from tomato, is likely to have been the most studied saponin (Safe et al., 1997).

Conclusively, obtaining of two clones from Pelargonium graveolens L, Herit., tolerate to fusarium wilt, There were true significant different between two clones and mother plant in leaves area characteristics and oil percentage. There were variation in DNA isolation between two clones and mother plant. As such we recommended propagating this clones and increasing its cultivated area to come over geranium wilt disease. 


\section{REFERENCES}

Alam, M. K., A. Shukla, R. S. Sattar, A. Singh, H. N. Samad, A. Gupta, M. L. Pandey, R. Ajaykumar, P.V. Sharma and S. P. S. Khanuja (2007): Healthy Plants for Health-A Complete Treatise on Major Diseases of Medicinal and Aromatic Plants and Their Management, Army Printing Press, Lucknow, India (2007).

Arafa, A. H., I. M. Harridy, A. M. Abo-Ela, M. A. M. Baiuomy and S. A. El-Morsy (1998): Studies on the commonly and newly occurring diseases of seven medicinal and aromatic plants and yield losses in relation to some agricultural practices in Egypt. Egypt. J. Appl. Sci; 13(7) page $41-60$.

Bi, Y. M., B. P. A. Commune, P. H. Goodwin, S. K. Raj and P. K. Saxena (1999): Resistance to Botrytis cinerea in scented geranium transformed with a gene encoding the antimicrobial protein AceAMPl, Plant Cell Rep. (18) 835-840.

British Pharmacopoeia (1963): The pharmaceutical press 17 Bloomsburg, square. W. C. I. London.

Dellaporta, S. L., J. Wood and J. B. Hicks (1983): A plant minipreparation: version II. Plant Mol Biol Report; 1:19-21.

Dhingra, O. D. and J. B. Sinclair (1995): .Basic plant pathology methods. $2^{\text {nd }}$ ed.CRC, Press, Inc. ,USA.

Fleisher, A. and Z. Fleisher, (1985): Yield and quality of essential oil from Pelargonium graveolens cultivated in Israel. J. Sci Food Agric 36:1047-1050

Gauri, S., S. Banerjee, L. Rahman, G. R. Mallavarapu, S. Sharma, Sushil-Kumar and S. Kumar (2000): An efficient in vitro procedurs for micropropagation and generation of somaclones of rose scented pelargonium. Plant Science - Limerick. 155: 2, 133 140; 22 ref.

Hammerschlag, F. A. (1992): Somaclonal variation. In: F.A. Hammerschlag and R.E. Litz, Editors, Biotechnology of Perennial Fruit Crops, CAB International, Wallingford, Oxon 35-36.

Hamouda, A. M. A. (2003): Propagation of some Medicinal and Aromatic Plants through tissue culture technique. PH. D. Thesis Agric. (Horticulture - Floriculture), Fac. Agric. Zagazig University.

Hassan Wafaa, F. E. (2006): Root rot and wilt diseases of pelargonium (Pelargonium graveolens L.) In Fayoum governorates. M. Sc. Thesis , Faculty of Agriculture, Fayoum University( Egypt ) 102. 
Lowry, P. H., N. J. Rosebrough, A. L. Farr and R. J. Randall (1951): Protein measurement with the Folin phenol reagent. Journal of Biol Chem; 193:265-75.

Matsumoto, K., M. L. Barbosa, L. A. C. Souza and J. B. Teixeira (1995): Race 1 fusarium wilt tolerance on banana plants selected by fusaric acid. Euphytica., 84(1): 67-71

Murashige, T. and F. Skoog (1962): A revised medium for rapid growth and bioassays with tobacco tissue culture. Physiol. Plantarum. 15: 473-496.

Olivain, C., and C. Alabouvette (1997): Colonization of tomato root by a non-pathogenic strain of Fusarium oxysporum. New Phytologist ,137: 481-494.

Olivain, C. and C. Alabouvette (1999): Process of tomato root colonisation by a pathogenic strain of $\mathrm{F} /$ tsarium oxysporum $\mathrm{f}$. $\mathrm{sp}$. lycopersici in comparison with a non-pathogenic strain. New Phytologist, 141: 497-510.

Osbourn, A. E. (1996): Preformed antimicrobial compounds and plant defense against fungal attack. Plant Cell, 8: 1821 -1831.

Recorbet, G., G. Bestel-Corre, E. Dumas-Gaudot, S. Gianinazzi and C. Alabouvette (1998): Differential accumulation of (3-1,3-glucanase and chitinase isoforms in tomato roots in response to either pathogenic or non-pathogenic strains of Fusarium oxysporum. Microbiological Research, 153:257-263.

Rines, H. W. (1986): Origin of tissue culture selected resistance to Helminthosporium victoriae toxin in heterologous susceptible acts. In: International Congress of Plant Tissue and Cell Culture (Abstract), University of Minnesota, Minneapolis, 212.

Safe, L. M., S. H. Safe, R. E. Subden and D. C. Morris (1997): Sterol content and polyene antibiotic resistance in isolates of Candica krusei, Candida parakrusei, and Candida tropic alis. Canadian Journal of Microbiology, 23: 398-401.

Sambrook, J., E. F. Fritsch and T. Maniatis (1989): Molecular cloning: $a$ laboratory manual, 2nd ed. Cold Spring Harbor, NY: Cold Spring Harbor Laboratory Press.

Saxena, G., P. C. Verma, L. Rahman, S. Banerjee, R. S. Shukla and S. Kumar (2008): Selection of leaf blight-resistant Pelargonium graveolens plants regenerated from callus resistant to a culture filtrate of Alternaria alternate. Crop Protection, 27, Issues 35, March-May, Pages 558-565. 
Skirvin, R. M. and J. Janick (1976): Tissue culture-induced variation in scented Pelargonium spp. J. Amer. Soc.Hort. Sci., 101 (3): 281-290.

Snedecor, G. W. and W. G. Cochran (1980): Statistical Methods. 7th ed. Iowa state Univ., press, Iowa, U. S. A.

Thakur, M., D. R. Sharma and S. K. Sharma (2002): In vitro selection and regeneration of carnation (Dianthus cayophyllus L.) plants resistant to culture filtrate of Fusarium oxysporum f. sp. dianthi, Plant Cell Rep., 20: 825-828.

Van, R. W. den Bulk (1991): Application of cell and tissue culture and in vitro selection for disease resistance breeding. A review, Euphytica ,56: 269-285.

Vernin, G., J. Metzger, D. Fraisse and C. Scharf (1983): Etude des huiles essentials par GC-SM-banque specma : essences de geranium. Parf. Cosm. Arom., 52:51-61

Webb, W. J. (1984): The Pelargonium Family. Croom. Helm, London.

Williams, J. G. K., A. R. Kubelik, K. J. Livak, J. A. Rafalski and S. V. TINGEY (1990): DNA polymorphisms amplified by arbitrarily primers are useful as genetic markers. Nucl. Acids Res., 18 : 6531 6535 . 


\section{إنتاج سلالات من العتر تتحمل الذبول من خلال مزارع الأنسجة}

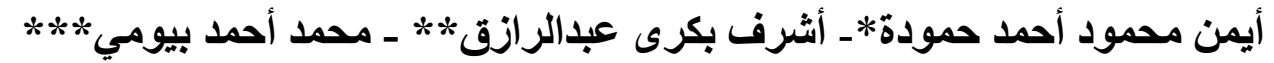

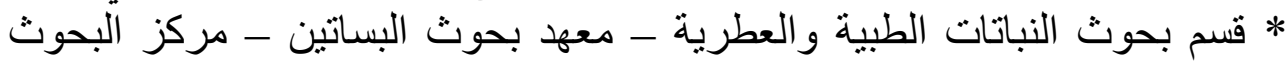

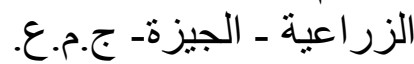

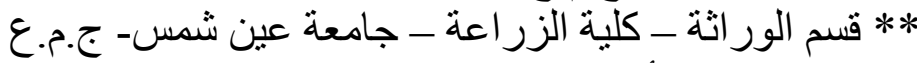

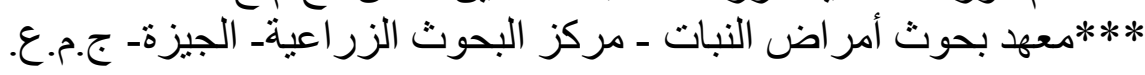

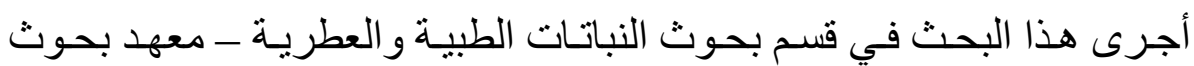

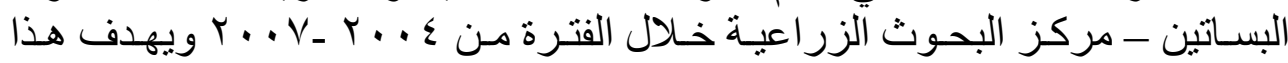

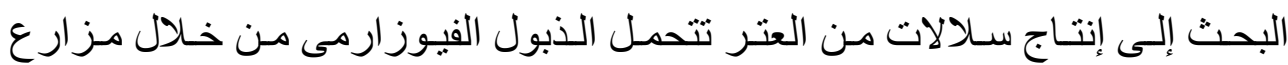

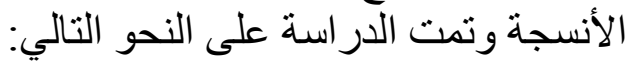

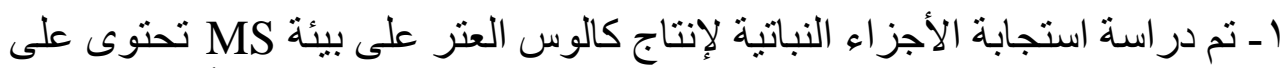

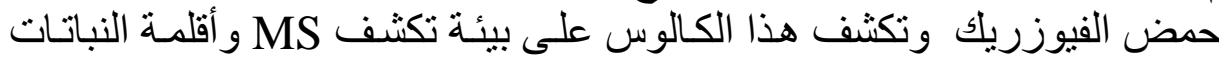

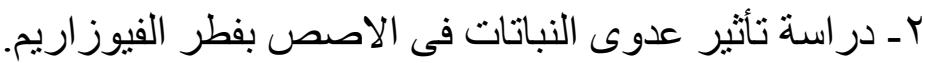

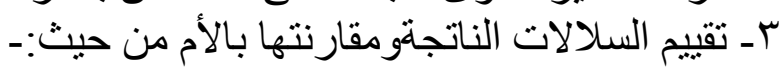

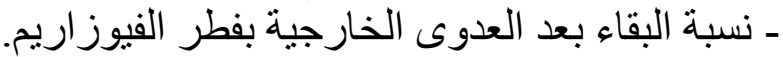

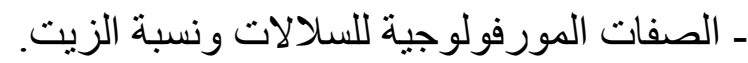
ـ ـ عزل DNA و البروتين للسلاتلات و الأم. وكانت أهم النتائج المتحصل عليها الأتى:-

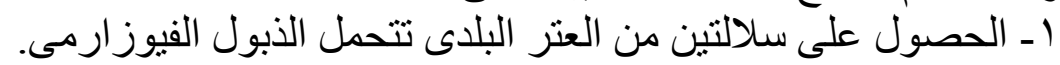

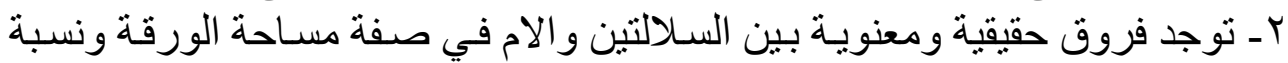
الزيت دون باقى الصفات المختبرة.

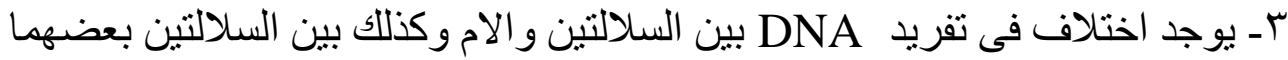

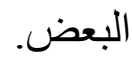
ع ـ ظهور نوع جديد من البروتين فى السلالتين لم يكن موجود فى الأم.

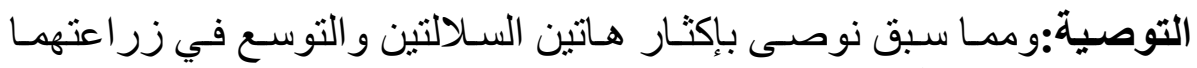
للتغلب على مرض الذبول فى العتر البلدي. 